\title{
POLISH SOCIETY IN THE LIGHT OF THE USE OF RENEWABLE ENERGY SOURCES
}

\author{
WOJCIECHOWSKA-SOLIS, $\mathrm{J}{ }^{*}-$ SOROKA, A. ${ }^{2}$ \\ ${ }^{1}$ Department of Agrobioengineering, University of Life Sciences in Lublin \\ Akademicka 13, PL-20-950 Lublin, Poland \\ ${ }^{2}$ Institute of Health Sciences, Department of Natural Sciences, Siedlce University of Natural \\ Sciences and Humanities \\ Konarskiego 2, PL-08-110 Siedlce, Poland \\ *Corresponding author \\ e-mail: julia.wojciechowska@up.lublin.pl \\ (Received 12 $2^{\text {th }}$ Sep 2017; accepted $15^{\text {th }}$ Jan 2018)
}

\begin{abstract}
The aim of the study was to determine the attitude of Polish society towards renewable energy sources and identify the benefits posed by actions that use renewable energy sources. A method of diagnostic survey was applied, conducting the study on the representative sample of 1067 respondents. The Statistica 10.1 GB program and the analysis of discriminant function were used in statistical analysis. It was shown that paying conscious attention to saving energy was the most important declaration of Polish society as the best way to save electricity. Polish citizens declared the use of energy-efficient sources of electricity, and in their opinion the greatest chance of use within the renewable energy sources had solar energy. In the opinion of Polish society, the greatest barrier to use the renewable energy sources is the lack of mechanisms supporting the reduction of energy intensity of the economy and the lack of policy coherence for sustainable development in terms of air protection. Additionally, the most important type of support that would encourage investing in the renewable energy sources is to raise funds from the ecological funds and European Union funds. The acquisition of renewable energy sources is highly influenced by the energy policy pursued by individual European Union countries, and the energy future depends on the political will and the capacity of societies to implement appropriate technologies.
\end{abstract}

Keywords: renewable energy sources, Polish society, barriers and motives, production support

\section{Introduction}

The demand for energy resources is continuously growing, and the reason for this tendency lies in the dynamic economic development and population growth (Warner and Jones, 2017). These factors caused that the energy resources in the form of nonrenewable resources started to decrease, making it necessary to search for alternative sources (Hodana et al., 2012). Another important problem related to the exploitation of natural resources is the progressing degradation of the natural environment, affecting the proper functioning of the population (Adewuyi and Awodumi, 2017).

A model of functioning global energy, created by Jones and Warner (2016), has shown that the energy sector in the coming years will not deal with meeting the needs of the industrial economy and individual consumers in providing the energy without a support of renewable energy sources (Ahmed et al., 2014). A high impact on the growing demand for energy have rapidly developing countries of Asia in particular, but also countries of Europe, America and Australia as well as the Pacific Islands (Betzold, 2016).

There is observed an increase in the intensity of promotional campaigns aimed at the reduction of greenhouse gas emission, which is also of a great importance while promoting investments on the production of renewable energy (Al-mulali et al., 2013). 
An example is Europe, where since 2008 the majority of new energy installations have been based on renewable energy sources (Hvelplund et al., 2013).

In 2013 the produced renewable energy accounted for only $19.1 \%$ of the world consumption (Gasparatos et al., 2017). however, by 2014 the number of countries that have adopted policies aimed at the production of renewable energy has increased 3,5 times compared to 2004. Today, this number has increased to 164 countries from all regions of the world (REN21, 2015). European Union directive on the use of energy from renewable sources assumes that this energy by 2020 will be used in $20 \%$ by the EU Member States (EC. Directive, 2009).

The studies carried out so far have shown the greatest demand for the energy from wind, biomass and the sun (Banshwar et al., 2017b), which is most widely used by USA, China, and in Europe by Germany and the United Kingdom (Hammons, 2008). An important issue undertaken by researchers is the protection of environmental resources as well as motives related to generating income as a result of using energy from renewable sources (Bergek and Mignon, 2017).

In the studies Poland, like Ireland, Portugal, Finland, Greece, Romania and other countries that joined the European Union, is classified in Europe as a developing country (Amri, 2017). For this group of countries there was demonstrated a strong correlation between the introduction of solutions related to renewable energy sources and the GDP growth as well as the possibility to employ the local population in the energy sector (Arellano and Bond, 1991). However, fossil fuels are still the main source of the energy in Poland. This leads to high damages in natural environment and health of the population, although Poland has the potential for the use of renewable energy sources, which currently is used only to a very small extent (Igliński et al., 2016b).

The aim of the study was to determine the attitude of Polish society towards renewable energy sources. The efforts were made to determine the benefits posed by activities that use renewable energy sources and to identify the motives of potential recipients to use different techniques of obtaining the energy from renewable sources.

\section{Methodology}

A method of diagnostic survey was used in the study. The research tool was a questionnaire, which included 5 closed-ended questions. While measuring the attitudes, a five-point Likert scale was applied, after the use of activities related to the construction and validation. There was calculated the index of scale reliability, where Cronbach's alpha was set at 0.84 . The methodological procedure allowed calculating the size of research sample, where the confidence level was set at 0.95 , the estimated size of fraction at 0.50 and the maximum error at 0.03 .

The sample size was selected from the whole adult population of Poland, which amounted to 31532048 persons (GUS, 2016). The sample size was set at 1067 respondents, who were chosen taking into account sex, place of residence, age and individual six Polish regions, and the number of respondents was representative for these regions: central - 220, southern - 222, eastern - 188, southwestern - 109, northwestern - 164 and northern - 164 persons. The study was conducted in September and October 2016.

The Statistica 10.1 GB program and the analysis of discriminant function were used in statistical analysis. The classification function was used in the form of calculating coefficients that were determined for each of created groups. Prior to the analysis there 
was examined a multivariate normality, verifying each variable for normality of distribution. It was assumed that the matrices of variances were homogeneous in groups. A standard deviation was not included due to a large number of respondents in each group. Statistically significant were those differences in means, of which the probability of randomness was less than $\mathrm{p}<0.05$.

\section{Research results}

\section{Saving energy in Polish households}

Paying conscious attention to the energy saving was the most common action pointed by Polish society as the best way to save electricity. Such declarations, to the most significant extent, occurred within the oldest age group at $\mathrm{p}<0.001$, as compared to the other two.

Regularly appeared, that the younger the group of responders, the less its interest in this way of saving energy. The opposite situation occurred in a declaration that the light is turned off in a situation of leaving the room. Significant differences occurred at $\mathrm{p}<0.001$, at the highest values of classification function in the case of the youngest group of respondents. The society, to a considerable extent, declared the use of energyefficient sources of electricity. Such declarations, to the highest degree, appeared at the age from 40 to 54 years. The model also includes activities related to indications concerning energy consumption when buying RTV/AGD devices and avoiding the use of standby mode in RTV/AGD devices (Table 1).

Table1. The level of saving electricity in Polish households

\begin{tabular}{|c|c|c|c|c|c|c|c|}
\hline \multirow[b]{2}{*}{ Means of saving the electricity } & \multicolumn{3}{|c|}{$\begin{array}{c}\text { Wilks' lambda: } \\
\text { 0.632 } \\
\text { F }=9.143 \text { p }<0.001\end{array}$} & \multicolumn{4}{|c|}{$\begin{array}{c}\text { Classification function (the age of } \\
\text { respondents) }\end{array}$} \\
\hline & 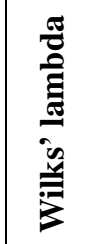 & 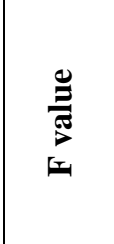 & $\frac{\bar{d}}{2}$ & 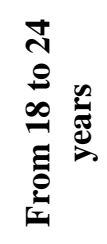 & 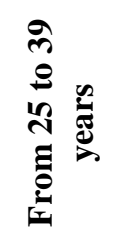 & 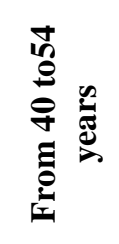 & 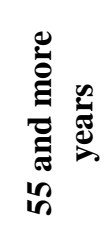 \\
\hline $\begin{array}{l}\text { I follow the labeling on the consumption of } \\
\text { electricity when buying RTV/AGD }\end{array}$ & 0.678 & 30.381 & $0.001^{*}$ & 0.212 & 0.482 & 0.587 & 0.286 \\
\hline $\begin{array}{l}\text { I consciously pay attention to energy } \\
\text { saving }\end{array}$ & 0.649 & 17.363 & $0.001^{*}$ & 1.908 & 2.041 & 2.775 & 3.053 \\
\hline $\begin{array}{c}\text { I always turn off the light when leaving the } \\
\text { room }\end{array}$ & 0.652 & 18.458 & $0.001^{*}$ & 3.123 & 2.856 & 2.719 & 1.484 \\
\hline I use energy-efficient sources of electricity & 0.721 & 4.999 & $0.019^{*}$ & 1.684 & 1.869 & 2.105 & 1.770 \\
\hline $\begin{array}{l}\text { I avoid the use of standby mode in } \\
\text { RTV/AGD devices }\end{array}$ & 0.616 & 2.865 & $0.036^{*}$ & 0.722 & 0.640 & 0.712 & 1.226 \\
\hline \multicolumn{4}{|l|}{ Constans } & 13.748 & 17.219 & 22.002 & 19.195 \\
\hline
\end{tabular}

*Level of significant difference at $\mathrm{p}<0.050$

Source: Author's own analysis based on study material 


\section{The future of renewable energy sources}

In the opinion of the society, renewable energy sources using solar energy are most likely to be used. The oldest respondents also perceived in biogas opportunity to produce renewable energy sources. This declaration at $\mathrm{p}<0.001$ was significantly the highest in relation to other groups. Respondents aged from 18 to 24 declared in substantially the highest degree, at $\mathrm{p}<0.001$, obtaining energy from sources related to water in the future, whereas respondents aged from 25 to 39 and from 40 to 54 years in the biomass. Apart from the oldest group surveyed, other groups also highly assessed the energy obtaining with the use of wind power installations (Table 2).

Table 2. Preferences regarding the future of various renewable energy sources

\begin{tabular}{|c|c|c|c|c|c|c|c|}
\hline \multirow[b]{2}{*}{$\begin{array}{c}\text { Type of renewable energy } \\
\text { sources }\end{array}$} & \multicolumn{3}{|c|}{$\begin{array}{c}\text { Wilks' lambda: } \\
0.713 \\
\text { F }=\mathbf{1 1 . 1 5 7} \mathbf{p}<0.001^{*}\end{array}$} & \multicolumn{4}{|c|}{$\begin{array}{l}\text { Classification function (the age of } \\
\text { respondents) }\end{array}$} \\
\hline & 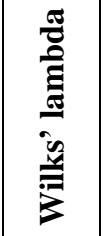 & 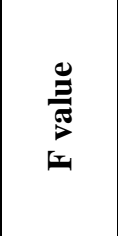 & $\frac{\bar{d}}{2}$ & 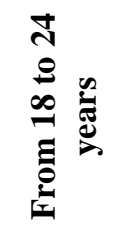 & 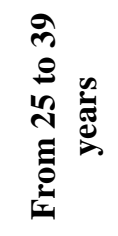 & 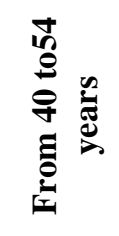 & 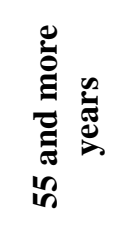 \\
\hline Water & 0.771 & 22.381 & $0.001^{*}$ & 1.113 & 0.915 & 0.296 & 0.391 \\
\hline Biogas & 0.758 & 17.162 & $0.001^{*}$ & 1.500 & 1.779 & 1.330 & 3.246 \\
\hline Biomass & 0.730 & 6.407 & $0.001^{*}$ & 0.879 & 1.194 & 1.264 & 0.546 \\
\hline Wind & 0.726 & 4.991 & $0.001^{*}$ & 1.280 & 1.389 & 1.466 & 0.677 \\
\hline Geothermal & 0.724 & 4.046 & $0.007^{*}$ & 0.038 & 0.146 & 0.060 & 0.847 \\
\hline Solar & 0.721 & 2.736 & $0.042^{*}$ & 4.422 & 4.414 & 4.694 & 4.916 \\
\hline \multicolumn{4}{|c|}{ Constans } & 16.654 & 19.275 & 19.246 & 21.474 \\
\hline
\end{tabular}

* Level of significant difference at $\mathrm{p}<0.050$

Source: Author's own analysis based on study material

\section{Investments related to renewable energy sources}

The respondents sought the most important benefit from the use of renewable energy in the protection of natural environment. It was a declaration significantly more often expressed by the groups aged 25-39 and 40-54, at $\mathrm{p}=0.006$. The opposite situation occurred in the declaration of benefits from savings in energy use. Significantly higher values of classification function, at $\mathrm{p}<0.001$, occurred in the youngest and the oldest groups of respondents, comparing to respondents aged 25-39 and 40-54. An important task for Polish society is to become independent from fossil fuels and energy security as well as the gradual independence from external sources. The reduction of greenhouse gas emissions was significantly more important, at $\mathrm{p}<0.001$, at the age group from 25 to 39 (Table 3). 
Table 3. The benefits of investing in renewable energy sources

\begin{tabular}{|c|c|c|c|c|c|c|c|}
\hline \multirow[b]{2}{*}{$\begin{array}{l}\text { Type the benefits of the use of } \\
\text { renewable energy sources }\end{array}$} & \multicolumn{3}{|c|}{$\begin{array}{l}\text { Wilks' lambda: } 0.632 \\
\mathrm{~F}=9.877 \mathrm{p}<0.001^{*}\end{array}$} & \multicolumn{4}{|c|}{$\begin{array}{l}\text { Classification function (the age of } \\
\text { respondents) }\end{array}$} \\
\hline & 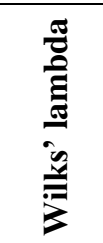 & $\frac{\mathscr{E}}{\mathbb{E}}$ & $\frac{\bar{d}}{a}$ & 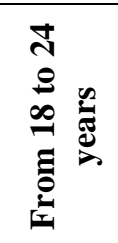 & 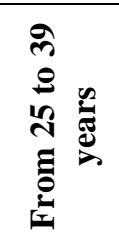 & 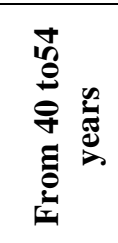 & 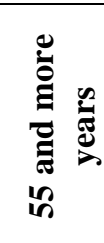 \\
\hline $\begin{array}{l}\text { Energy securityand the gradual } \\
\text { dependence on external sources }\end{array}$ & 0.661 & 10.949 & $0.001^{*}$ & 1.732 & 2.313 & 1.637 & 2.410 \\
\hline Local/regional development & 0.677 & 16.876 & $0.001^{*}$ & 0.535 & 0.715 & 0.898 & 1.098 \\
\hline $\begin{array}{c}\text { Reduction of greenhouse gas } \\
\text { emissions }\end{array}$ & 0.662 & 11.167 & $0.001^{*}$ & 0.864 & 1.236 & 0.618 & 0.078 \\
\hline Savings in energy use & 0.653 & 7.880 & $0.001^{*}$ & 3.504 & 3.046 & 3.008 & 3.747 \\
\hline Independence from fossil fuels & 0.645 & 4.767 & $0.002^{*}$ & 1.950 & 2.188 & 2.356 & 1.646 \\
\hline Protection of natural environment & 0.643 & 4.115 & $0.006^{*}$ & 3.840 & 4.282 & 4.165 & 3.845 \\
\hline \multicolumn{4}{|c|}{ Constans } & 21.563 & 25.335 & 26.497 & 26.183 \\
\hline
\end{tabular}

*Level of significant difference at $\mathrm{p}<0.050$

Source: Author's own analysis based on study material

\section{Barriers in the use of renewable energy sources}

In the opinion of Polish society, the greatest barrier in the use of renewable energy sources is the lack of mechanisms supporting the reduction of energy intensity of the economy. Significantly higher values of declarations, at $p=0.002$, appeared among respondents from the two oldest groups, whereas the youngest groups, to a significantly higher degree, at $\mathrm{p}<0.001$, drew attention to the lack of policy coherence for sustainable development in the issue of air protection. Especially for residents aged 4054 , a significant obstacle was the lack of stability of the policy to promote renewable energy sources, associated with occurring monopoly on the energy market. The model also includes: barriers associated with exploitation of energy networks infrastructure, the increase of energy prices resulting from the lack of competition on the wholesale market and too complicated procedures of obtaining permits (Table 4).

\section{Types of support for the production of renewable energy sources}

It has been declared that the most important support which would encourage investments in renewable energy sources is to raise funds from the ecological funds and European Union funds. Especially respondents of the two oldest age groups expect such kind of support. Expectations are also directed towards relief from excise tax for the energy produced. Such solutions, to the most significant extend, at $\mathrm{p}<0.001$, are expected by residents aged 40-54. The model also includes expectations of legal nature that are associated with the volume commitments (Table 5). 
Table 4. Barriers affecting the use of renewable energy sources

\begin{tabular}{|c|c|c|c|c|c|c|c|}
\hline \multirow[b]{2}{*}{ Type of barrier } & \multicolumn{3}{|c|}{\begin{tabular}{|c|} 
Wilks' lambda: \\
0.628 \\
F $=\mathbf{1 0 . 1 2 9}$ p $<0.001^{*}$ \\
\end{tabular}} & \multicolumn{4}{|c|}{$\begin{array}{c}\text { Classification function (the age of } \\
\text { respondents) }\end{array}$} \\
\hline & 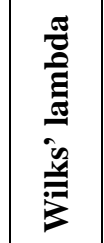 & 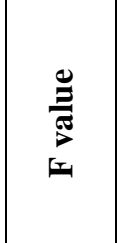 & $\frac{\bar{d}}{2}$ & 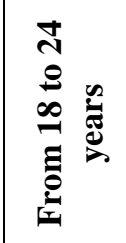 & 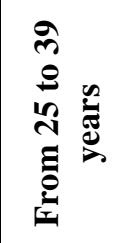 & 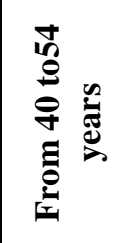 & 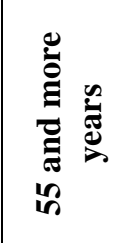 \\
\hline $\begin{array}{l}\text { The lack of stable policy to promote } \\
\text { renewable energy sources - monopoly of the } \\
\text { energy market }\end{array}$ & 0.699 & 26.847 & $0.001^{*}$ & 0.998 & 1.377 & 2.308 & 1.137 \\
\hline $\begin{array}{l}\text { Lack of coherent policy on sustainable } \\
\text { development in air protection }\end{array}$ & 0.651 & 8.544 & $0.001^{*}$ & 2.214 & 2.427 & 1.818 & 1.440 \\
\hline $\begin{array}{l}\text { The lack of mechanisms to support the } \\
\text { reduction of energy intensity of the economy }\end{array}$ & 0.641 & 4.721 & $0.002^{*}$ & 2.532 & 2.712 & 2.905 & 3.163 \\
\hline Exploited infrastructure of power grids & 0.638 & 3.829 & $0.009^{*}$ & 1.289 & 1.536 & 1.042 & 1.635 \\
\hline $\begin{array}{c}\text { The increase in energy prices resulting from } \\
\text { the lack of competition in the wholesale } \\
\text { market }\end{array}$ & 0.636 & 2.847 & $0.036^{*}$ & 1.993 & 2.014 & 1.613 & 2.000 \\
\hline $\begin{array}{l}\text { Too complicated procedures for obtaining } \\
\text { permits and energy accounting }\end{array}$ & 0.631 & 1.037 & 0.375 & 1.136 & 1.190 & 1.341 & 1.335 \\
\hline \multicolumn{4}{|l|}{ Constans } & 17.850 & 23.193 & 23.440 & 23.433 \\
\hline
\end{tabular}

*Level of significant difference at $\mathrm{p}<0.050$

Source: Author's own analysis based on study material

Table 5. Type of support that will encourage investments in renewable energy sources

\begin{tabular}{|c|c|c|c|c|c|c|c|}
\hline \multirow[b]{2}{*}{ Type of support } & \multicolumn{3}{|c|}{$\begin{array}{c}\text { Wilks' lambda: } \\
\text { 0.727 } \\
\text { F }=\mathbf{8 . 0 1 1} \text { p }<0.001^{*}\end{array}$} & \multicolumn{4}{|c|}{$\begin{array}{l}\text { Classification function (the age of } \\
\text { respondents) }\end{array}$} \\
\hline & 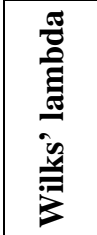 & 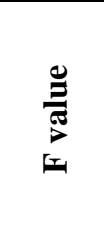 & $\frac{\bar{d}}{2}$ & 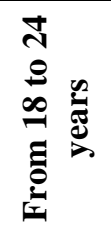 & 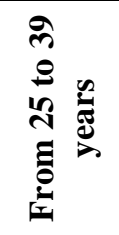 & 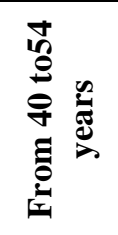 & 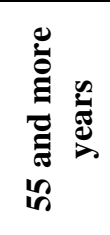 \\
\hline Tax (relief in excise tax) & 0.761 & 11.547 & $0.001^{*}$ & 2.469 & 2.608 & 3.107 & 2.257 \\
\hline Legal (quantity commitments) & 0.756 & 9.789 & $0.001^{*}$ & 1.788 & 2.146 & 1.502 & 2.193 \\
\hline $\begin{array}{l}\text { Financial (subsidies from environmental } \\
\text { funds and EU funds) }\end{array}$ & 0.740 & 4.436 & $0.004^{*}$ & 4.723 & 4.383 & 4.881 & 4.959 \\
\hline \multicolumn{4}{|l|}{ Constans } & 18.193 & 19.970 & 22.652 & 23.177 \\
\hline
\end{tabular}

*Level of significant difference at $\mathrm{p}<0.050$

Source: Author's own analysis based on study material

\section{Discussion}

The aim of the study was to determine the attitude of Polish society towards renewable energy sources. Currently, Poland is a country where almost $90 \%$ of the energy is derived from coal and lignite that is from natural energy sources. 
Recommendations of the European Union as well as the willingness and readiness of Poland to environmental protection tend to obtaining energy from renewable sources (Paska and Surma, 2014; Igliński et. al., 2016a).

The conducted study showed that in Polish society there is awareness of the need to save the energy, especially this identified with the electricity. This approach is especially supported by older part of the population, although the level of declarations that the light is turned off in a situation of leaving the room indicates that also younger generations have a sense of concern for the energy.

The most popular way is to obtain the energy from solar collectors. It is a natural and targeted action, concerning the large promotion and additional investment of these projects from the EU funds. Confirmation of the validity of such actions is the West Pomeranian region, in which among holders of solar collectors there have been reported savings even up to $90 \%$ in summer and $40 \%$ in winter (Igliński et al., 2013). However, without financial support from the EU funds, as this type of installation is rather expensive, economic savings on such scale would not take place (Lambert and Silva, 2012).

It should be noted, however, that countries experienced in the production of energy from renewable sources prefer obtaining the energy from wind and biomass (Branshwar et al., 2017b).

The results of conducted studies are synonymous with European Union directives, which like the Polish society perceive the future of energy also inheat pumps and biomass stoves. In addition, such actions are aimed at reducing emission of greenhouse gases, of which excessive production has increasingly negative impact on healthy functioning of European societies. Similar expectations appeared also in Ireland, which like Poland has a problem with fossil fuels (Murphy et al., 2016).

The main benefits of the use of renewable energy sources are nature protection and savings associated with this kind of energy. These two factors are very important for developing countries, also Poland (Banshwar et. al., 2017a). Such declarations were also expressed by respondents in the conducted study.

This is a confirmation of the studies conducted in Sweden, focused on environmental issues and environmental protection (Bergek and Mignon, 2017).

An important issue for the Polish population is to become less reliant on fossil fuels, and energy security as well as gradual independence from obtaining energy from external sources (Lund et al., 2015). The local development is also very important. Through the introduction on the large scale devices for obtaining alternative energy, there is the possibility of creating new jobs for people operating these devices (Igliński et. al., 2012). Moving away from traditional fossil fuels to renewable energy sources, Europe is also able to eliminate nuclear power plants, which significantly damage the environment (Connolly et. al., 2016).

There were pointed out the most important barriers in the use of renewable energy sources which are the lack of support mechanisms to reduce the energy intensity of the economy and the lack of policy coherence for sustainable development of air protection. Such arguments have already been confirmed in the studies conducted by Igliński et al. (2012). Additionally, such barriers as the lack of stability of the policy to promote renewable energy sources, exploited infrastructure of energy network, higher energy prices resulting from the lack of competition in the wholesale market and overly complicated procedures for obtaining were also very important (Igliński et. al., 2012; Huijts et. al., 2012) for respondents taking part in the study. 
Respondents declared that the most important support which would encourage investments in renewable energy sources is to raise funds from subsidies of environmental funds and European Union funds. Expectations are also directed towards reliefs from excise tax for the energy produced and quantity commitments. It is also a focus on generating economic income, which is becoming a motivation to invest in renewable energy sources (Bergek and Mingnon, 2017). The conducted study and analysis of their results indicate a great importance of energy policy implemented by individual European Union countries, and the future of energy depends on political will and the capacity of societies to implement appropriate technologies (Lund and Hvelplund, 2012).

\section{Conclusions}

1. In Polish society there is awareness of the need to save the energy, especially this identified with the electricity. This approach is especially supported by older part of the population.

2. The most popular way to obtain the energy is the use of solar collectors.

3. The main benefits of the use of renewable energy sources are nature protection and savings associated with this kind of energy. An important issue for the Polish population is to become less reliant on fossil fuels, and energy security as well as gradual independence from obtaining energy from external sources.

4. That the most important support which would encourage investments in renewable energy sources is to raise funds from subsidies of environmental funds and European Union funds.

\section{REFERENCES}

[1] Adewuyi, A., Awodumi, O. B. (2017): Renewable and non-renewable energy-growthemissions linkages: Review of emerging trends with policy implications. - Renewable and Sustainable Energy Reviews 69: 275-291.

[2] Ahmed, S., Islam, M. T., Karim, M. A., Karim, N. M. (2014): Exploitation energy for sustainable development and overcoming power crisis Bangladesh. - Renewable Energy 72: 223-235.

[3] Al-mulali, U., Fereidouni, H. G., Lee, J. Y. M., Sab, C. N. B. C. (2013): Examining the bi-directional long-run relationship between renewable Energy consumption and GDP growth. - Renewable and Sustainable Energy Reviews 22: 209-222.

[4] Amri, F. (2017): Intercourse across economic growth, trade and renewable energy consumption in developing and developed countries. - Renewable and Sustainable Energy Reviews 69: 527-534.

[5] Arellano, M.., Bond, S. (1991): Some test of specification for panel data: Monte Carlo evidence and an application to employment equations. - The Review of Economic Studies 58(2): 277-297.

[6] Banshwar, A., Sharma, N. K., Sood, Y. R., Shrivastava, R. (2017a): Market based procurement of energy and ancillary services from Renewable Energy Sources in deregulated environment. - Renewable Energy 101: 1390-1400.

[7] Banshwar, A., Sharma, K. N., Sood, Y. R., Shrivastava, R. (2017b): Renewable energy sources as a new participant in ancillary service markets. - Energy Strategy Reviews 18: 106-120.

[8] Betzold, C. (2016): Fuelling the Pacific: Aid for renewable energy across Pacific Island countries. - Renewable and Sustainable Energy Reviews 58: 311-318. 
[9] Bergek A., Mignon, I. (2017): Motives to adopt renewable electricity technologies: Evidence from Sweden. - Energy Policy 106: 547-559.

[10] Conolly, D., Lund, H., Mathiesen, B. V. (2016): Smart Energy Europe: The technical and economic impact of the potential 100\% renewable energy scenario for the European Union. - Renewable and Sustainable Energy Reviews 60: 1634-1653.

[11] EC. Directive. (2009): 2009/28/EC on the promotion of the use of energy from renewable sources. - OJ Eur Union L 140: 16-62.

[12] Gasparatos, A., Doll, C. N. H., Esteban, M., Ahmed, A., Olang, T. A. (2017): Renewable energy and biodiversity: Implications for transitioning to a Green Economy. - Renewable and Sustainable Energy Reviews 70: 161-184.

[13] GUS (2016):Balance at 06.30.2016 according to GUS. Population. Size and structure by territorial division. Warsaw. - www.gov.pl.

[14] Hammons, T. (2008): Integrating renewable energy sources into European grids. International Journal of Electrical Power \& Energy Systems 30: 462-475.

[15] Hodana, M., Holtzer, G., Kalandyk, K., Szymańska, A., Szymański, B., ŻymanowskaKumon, S. (2012): Odnawialne źródła energii. Poradnik. - Helios, Kraków (in Polish).

[16] Huijts, N. M. A., Molin, E. J. E., Steg, L. (2012): Psychological factors influencing sustainable energy technology acceptance: a review-based comprehensive framework. Renewable and Sustainable Energy Reviews 16: 525-531.

[17] Hvelplund, F., Möller, B., Sperling, K. (2013): Local ownership, smart energy systems and better wind power economy. - Energy Strategy Reviews 1: 164-170.

[18] Igliński, B., Buczkowski, R., Cichosz, M., Piechota, G. (2013): Renewable energy production in the Zachodniopomorskie Voivodeship (Poland). - Renewable and Sustainable Energy Reviews 27: 768-777.

[19] Igliński, B., Buczkowski, R., Iglińska, A. Cichosz, M., Piechota, G., Kujawski, W. (2012): Agricultural biogas plants in Poland: Investment process, economical and environmental aspects, biogas potential. - Renewable and Sustainable Energy Reviews 16: 4890-4900.

[20] Igliński, B., Cichosz, M., Kujawski, W., Plaskacz-Dziuba, M., Buczkowski, R. (2016a): Helioenergy in Poland - Current state, surveys and prospects. - Renewable and Sustainable Energy Reviews 58: 862-870.

[21] Igliński, B., Iglińska, A., Cichosz, M., Kujawski, W., Buczkowski, R. (2016b): Renewable energy production in the Łódzkie Voivodeship. The PEST analysis of the RES in the voivodeship and in Poland. - Renewable and Sustainable Energy Reviews 58: 737-750.

[22] Jones, G. A., Warner, K. J. (2016): The 21st century population-energy-climate nexus. Energy Policy 93: 206-212.

[23] Lambert, R. J., Silva, P. P. (2012): The challenges of determining the employment effects of renewable energy. - Renewable and Sustainable Energy Reviews 16: 4667-4674.

[24] Lund, H., Hvelplund, F. (2012): The economic crisis and sustainable development: The design of job creation strategies by use of concrete institutional economics. - Energy 43: 192-200.

[25] Lund, P., Lindgren, J., Mikkola, J., Salpakari, J.(2015): Review of energy system flexibility measures to enable high levels of variable renewable electricity. - Renewable and Sustainable Energy Reviews 45: 785-807.

[26] Murphy, F., Sosa, A., McDonnell, K., Devlin, G. (2016): Life cycle assessment of biomass-to-energy systems in Ireland modelled with biomass supply chain optimization based on greenhouse gas emission reduction. - Energy 109: 1040-1055.

[27] Paska, J., Surma, T. (2014): Electricity generation from renewable sources in Poland. Renewable Energy 71: 286-294.

[28] REN21. (2015): Renewables (2015): Global Status Report. - REN21 Secretariat, Paris.

[29] Warner, K. J., Jones, G. A. (2017): A population-induced renewable energy timeline in nine world regions. - Energy Policy 101: 65-76. 